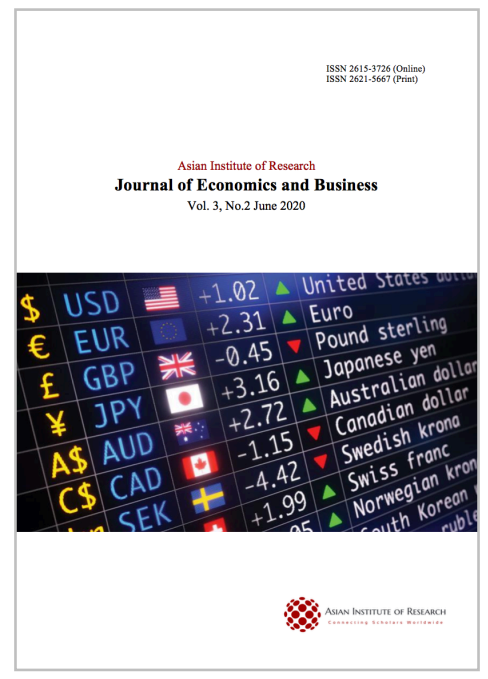

Journal of Economics and Business

Keho, Yaya. (2020), Determinants of Import Demand in Cote d'Ivoire: The Role of Expenditure Components. In: Journal of Economics and Business, Vol.3, No.2, 924-933.

ISSN 2615-3726

DOI: 10.31014/aior.1992.03.02.249

The online version of this article can be found at: https://www.asianinstituteofresearch.org/

Published by:

The Asian Institute of Research

The Journal of Economics and Business is an Open Access publication. It may be read, copied, and distributed free of charge according to the conditions of the Creative Commons Attribution 4.0 International license.

The Asian Institute of Research Journal of Economics and Business is a peer-reviewed International Journal. The journal covers scholarly articles in the fields of Economics and Business, which includes, but not limited to, Business Economics (Micro and Macro), Finance, Management, Marketing, Business Law, Entrepreneurship, Behavioral and Health Economics, Government Taxation and Regulations, Financial Markets, International Economics, Investment, and Economic Development. As the journal is Open Access, it ensures high visibility and the increase of citations for all research articles published. The Journal of Economics and Business aims to facilitate scholarly work on recent theoretical and practical aspects of Economics and Business. 


\title{
Determinants of Import Demand in Cote d'Ivoire: The Role of Expenditure Components
}

\begin{abstract}
Yaya Keho
${ }^{1}$ Ecole Nationale Supérieure de Statistique et d'Economie Appliquée (ENSEA) Abidjan. Tel.: (+225) 224441 24, Fax: (+225) 224851 68. 08 BP 03 Abidjan 08, Côte d'Ivoire. Email: yayakeho@yahoo.fr

Abstract

This study examines the relationship between aggregate imports and the individual components of expenditure in Cote d'Ivoire over the period from 1980 to 2017. The autoregressive distributed lag model is used to test and estimate the long and short-run import elasticities with respect to the expenditure components. The study finds evidence of a long-run relationship between aggregate imports, the expenditure components, domestic and import prices. The long-run import demand in Cote d'Ivoire is affected positively by domestic price, negatively by foreign price and positively by all expenditure components except exports which effect is insignificant. Furthermore, there are significant differences in the long and short-run elasticities of imports with respect to the different components of final expenditure. Final consumption expenditure and investment expenditure are among the major determinants of aggregate import demand in the long run. In the short run, all expenditure components are positively related to import growth, with consumption expenditure having the highest effect on import growth. The findings of the study indicate that the use of aggregate expenditure variable in the import demand function leads to aggregation bias because different components of final expenditure have different import contents. We also show that the relative price formulation is inappropriate in estimating import demand function for Cote d'Ivoire.
\end{abstract}

Keywords: Import Demand, Expenditure Components, ARDL, Cote d'Ivoire

JEL Classifications: C22, F10, F41

\section{INTRODUCTION}

International trade is widely acknowledged as an engine for economic development. It promotes domestic efficiency, international specialization and competitiveness, leading to economic growth. In this context, empirical investigation of import demand function has gained much literature in international economics over the past three decades. For policy purposes such as the balance of payment problems, it is important to know the driving factors of import demand and predict whether the balance of payment is deteriorating or not.

Most empirical studies have estimated import demand functions within the traditional framework by relating the volume of imports to domestic real income and relative import price (e.g., Mwega, 1993; Sinha, 1997; Bahmani- 
Oskooee and Niroomand, 1998; Tang and Nair, 2002; Tang, 2003; Dutta and Ahmed, 2004; Tsionas and Christopoulos, 2004; Chang et al., 2005; Babatunde and Egwaikhide, 2010; Modeste, 2011 ; Nwogwugwu et al., 2015 ; Mugableh, 2017). However, a major limitation of these studies is that they have used a single demand variable (e.g., GDP) as an explanatory variable in import demand function. The use of a single expenditure variable may lead to aggregation bias because different components of final expenditure may have different import contents (Giovannetti, 1989). Moreover, an import model that embodies disaggregate demand variables among the regressors shows better fit and forecast than a model with a single demand variable.

A number of studies have used disaggregated components of expenditure together with the relative price variable to estimate aggregate import demand functions. For instance, Abbott and Seddighi (1996) estimate the import demand function for United Kingdom and found significant differences between elasticities of import demand with respect to consumption expenditure, investment expenditure and exports. Import demand is more sensitive to changes in consumption expenditure as compared to changes in export and investment expenditure. In the case of Malaysia, Mohammed and Tang (2000) report that the macroeconomic components of final demand expenditure namely public and private consumption expenditure, investment expenditure and exports, are all important in determining demand for imports in both the long-run and the short run. Min et al. (2002) reveal that import demand in Korea is positively affected by consumption and export expenditure, whereas it is negatively affected by relative prices and investment expenditure. Tang (2003) finds export expenditure to have the biggest impact on import demand in China followed by investment, final consumption and relative price. Narayan and Narayan (2005) analyze the import demand behavior for Fiji during the period from 1970 to 2000 . They introduce relevant variables such as relative prices, total consumption, investment expenditure and export expenditure. Their results indicate that import demand is inelastic and statistically significant with respect all the explanatory variables in both the long-run and the short-run. Fosu (2008) analyses the behaviour of Ghana's imports during the period 1970-2002. Using disaggregated expenditure components of total national income, he finds inelastic import demand for all the expenditure components and relative price. In the long-run, investment and exports were the major determinant of movements in imports in Ghana. In the short run household and government consumption expenditures are the major determinants of import demand. Import demand is not very sensitive to price changes. In the case of Turkey, Guncavdi and Ulengin (2008) establish that private consumption and export expenditure are the most determinants of imports in the long run while consumption and investment expenditures are dominant factors in the short run. Government expenditure is found to have no significant impact on import demand in Turkey. In a time series analysis of demand function for Cote d'Ivoire over the period 1970 to 2007, N'Guessan and Yue (2010) confirm the leading role of investment and exports expenditures as the main determinants of imports in Cote d'Ivoire in the long run. In the short run, consumption expenditures are the major driver of import demand. The variable of relative price has no significant effect on import demand both in long and short run. Chani et al. (2011) examine the import demand function for Pakistan. They find that import demand is affected positively and significantly by all expenditure components. On the contrary, the relative prices have negative but insignificant relationship with import demand. Ziramba (2012) investigate the relationship between South African aggregate imports and expenditure components and the relative price of imports for the period $1970-2009$. He finds that different components of final demand expenditure have different impacts on aggregate import demand in both the short and long-run run. Muhammad and Zafar (2016) estimate the long run and short run of import demand function of Pakistan during the period 1973-2013. They find that import demand has both long- and short-run relationship with final consumption expenditure, investment expenditure, government consumption expenditure, exports, foreign direct investment, and exchange rate. Chantha et al. (2018) examine the case of Cambodia and find that relative prices and exchange rates have negative effects on import demand both in long and short run, while exports have positive effect on import demand. Foreign direct investment and final consumption expenditure have insignificant impact on import demand.

The objective of this study is to examine the import demand function and estimate the effect of individual components of expenditure on imports in Cote d'Ivoire over the period from 1980 to 2017. We disaggregate total expenditure into final consumption expenditure, investment and exports. At the methodological level, we use three alternative methods for estimating long run relationships, i.e. ARDL, FOLS and DOLS. These methods account for possible endogeneity of explanatory variables and have better small sample properties. We use these methods for gauging the sensitivity of the results to different estimation techniques. Furthermore, contrary to N'Guessan 
and Yue (2010) and other empirical studies which use relative price, we introduce import and domestic prices as two explanatory variables and test the assumption of price homogeneity. We contend that relative price formulation should not be imposed a priori but needs to be tested empirically. If the price homogeneity assumption does not hold, estimates from standard import demand function using relative price may be misleading. Our empirical results provide evidence against the price homogeneity assumption.

The balance of the paper is organized as the following way. Section 2 describes the econometric framework of the empirical study. Section 3 consists of the discussion of the empirical results. Section 4 provides concluding remarks and policy implications of the study.

\section{ECONOMETRIC FRAMEWORK}

\subsection{Model Specification}

Our aim in this study is to investigate the determinants of aggregate imports in Cote d'Ivoire with a focus on expenditure components. The traditional and popular import demand function is specified as follows:

$$
\ln \mathrm{M}_{\mathrm{t}}=\gamma_{0}+\gamma_{1} \ln \mathrm{Y}_{\mathrm{t}}+\gamma_{2} \ln \mathrm{PD}_{\mathrm{t}}+\gamma_{3} \ln \mathrm{PM}_{\mathrm{t}}+\mu_{\mathrm{t}}
$$

where $\ln \mathrm{M}_{\mathrm{t}}$ is the natural logarithm of real imports of goods and services, $\ln Y_{\mathrm{t}}$ is the natural logarithm of real income, $\operatorname{lnPD} t$ is the natural logarithm of the price of domestically produced goods and services, $\ln \mathrm{PM}_{\mathrm{t}}$ is the natural logarithm of the price of imported goods and services, and $\mu_{\mathrm{t}}$ is an error term which is normally distributed with mean zero and constant variance.

Giovannetti (1989) has proved that the use of a single aggregate expenditure variable in the aggregate import demand function may result in aggregation bias because different components of final expenditure may have different import contents. Following Giovannetti (1989), Abbott and Seddighi (1996), Min et al. (2002) and Narayan and Narayan (2005), the real domestic income variable $\left(\mathrm{Y}_{\mathrm{t}}\right)$ is decomposed into three broad components: consumption expenditure, investment expenditure and export expenditure. Thus, the empirical import demand function to be estimated in the present study is specified as follows:

$$
\ln M_{t}=\beta_{0}+\beta_{1} \ln C E_{t}+\beta_{2} \ln K_{t}+\beta_{3} \ln X_{t}+\beta_{4} \ln P_{t}+\beta_{5} \ln P M_{t}+\mu_{t}
$$

where $\mathrm{CE}_{t}$ is the real value of final consumption expenditure, $\mathrm{K}_{t}$ is the real value of gross capital formation and $\mathrm{X}_{t}$ is the real value of exports of goods and services. We expect $\beta_{1}, \beta_{2}, \beta_{3}$, and $\beta_{4}$ to be positive, while $\beta_{5}$ is expected to be negative.

In our empirical model, we have used two separate price variables instead of the relative import price, to capture the effects of prices on imports. Most existing empirical studies follow the standard theory of demand that assumes that import demand function is homogeneous of degree zero in prices and income (Deaton and Muellbauer, 1980). This implies that if one multiplies all prices and money income by a positive number, the volume of imports will remain unchanged. This assumption allows the import demand function to be expressed as a function of real income and relative price of imports defined as the ratio of import price to domestic price. The use of relative price attenuates any collinearity that may exist between domestic and import prices. However, it implies that the effects of import price and domestic price are equal in magnitude but opposite in sign, that is: $\beta_{4}+\beta_{5}=0$. If this restriction does not hold, estimation from relative price formulation can lead to misleading results (Murray and Ginman, 1976; Urbain, 1993). Contrary to previous studies including Ziramba and Bbuku (2003), Narayan and Narayan (2005), Chimobi and Ogbonna (2008), N'Guessan and Yue (2010), Bathalomew (2010), Chani et al. (2011), Yin and Hamori (2011), Marbuah (2013), and Ibrahim and Ahmed (2017), we do not postulate a priori this restriction and argue that price homogeneity hypothesis should be tested.

\subsection{Data Description}

This study uses variables comprising real final consumption expenditure (CE), real gross capital formation (K), real exports of goods and services (X), real imports of goods and services (M), domestic price (PD) and import 
price (PM). The data cover the period from 1980 to 2017 and were obtained from the 2019 World Development Indicators of World Bank. Import unit value index $(2000=100)$ was used as a proxy for import price, GDP deflator $(2000=100)$ was used as a proxy for domestic price index. We use the import unit value index and the export unit value index to convert nominal data on imports and exports in constant local currency. Real data on consumption and capital formation were obtained using the GDP deflator. Furthermore, all data are expressed in natural logarithmic form. This functional form provides elasticity coefficients directly. Studies including Doroodian et al. (1994), Sinha (1997) and Raijal et al. (2000) have shown that the log linear transformation provides more reliable estimates compared to linear transformation.

Table 1. Descriptive Statistics and Correlation Matrix

\begin{tabular}{|c|c|c|c|c|c|c|}
\hline Variables & $\ln \mathrm{M}$ & $\operatorname{lnCE}$ & $\ln K$ & $\ln X$ & $\ln \mathrm{PD}$ & $\ln P M$ \\
\hline \multicolumn{7}{|c|}{ Panel A: Summary statistics } \\
\hline Mean & 28.392 & 29.409 & 27.556 & 28.134 & 4.459 & 4.622 \\
\hline Median & 28.486 & 29.415 & 27.462 & 28.345 & 4.579 & 4.605 \\
\hline Maximum & 29.081 & 30.012 & 28.499 & 28.793 & 5.127 & 5.369 \\
\hline Minimum & 27.205 & 29.043 & 26.671 & 26.982 & 3.637 & 3.871 \\
\hline Std. dev. & 0.410 & 0.222 & 0.481 & 0.530 & 0.493 & 0.463 \\
\hline Skewness & -0.618 & 0.700 & 0.281 & -0.534 & -0.211 & 0.038 \\
\hline Kurtosis & 3.253 & 3.450 & 2.607 & 1.820 & 1.538 & 1.786 \\
\hline Jarque-Bera & $2.527^{*}$ & $3.427^{*}$ & $0.745^{*}$ & $4.015^{*}$ & $3.665^{*}$ & $2.341^{*}$ \\
\hline Probability & 0.282 & 0.180 & 0.688 & 0.134 & 0.159 & 0.310 \\
\hline \multicolumn{7}{|c|}{ Panel B: Correlation matrix } \\
\hline $\ln \mathrm{M}$ & $1.000^{*}$ & & & & & \\
\hline $\operatorname{lnCE}$ & $0.719^{*}$ & $1.000^{*}$ & & & & \\
\hline $\ln K$ & $0.584^{*}$ & $0.534^{*}$ & $1.000^{*}$ & & & \\
\hline $\ln X$ & $0.833^{*}$ & $0.672^{*}$ & $0.300^{* *}$ & $1.000^{*}$ & & \\
\hline $\operatorname{lnPD}$ & $0.846^{*}$ & $0.847^{*}$ & $0.424^{*}$ & $0.889^{*}$ & $1.000^{*}$ & \\
\hline $\operatorname{lnPM}$ & $0.575^{*}$ & $0.814^{*}$ & $0.392^{*}$ & $0.671^{*}$ & $0.892^{*}$ & $1.000^{*}$ \\
\hline
\end{tabular}

Table 1 shows the descriptive statistics of the logarithmic transformation of the variables. The average real imports over the sample period was about 28.392 with a maximum of 29.081 and a minimum of 27.205 . The import price index averaged 4.622 with a maximum of 5.369 and a minimum of 3.871. The probability values from the JarqueBera statistic suggest that all the variables are normally distributed. The correlation matrix indicates positive relationships among the variables.

Table 2. Structure of imports by commodity types (as share of total imports)

\begin{tabular}{llllllll}
\hline & 2008 & 2010 & 2012 & 2014 & 2016 & 2017 & $2002-2017$ \\
\hline Consumer goods & 39.20 & 39.03 & 39.97 & 39.72 & 48.23 & 50.75 & 42.82 \\
Intermediate goods & 48.92 & 35.63 & 41.60 & 38.48 & 29.35 & 25.26 & 36.54 \\
Capital goods & 11.88 & 25.34 & 18.43 & 21.80 & 22.42 & 23.99 & 20.64 \\
\hline Total & $\mathbf{1 0 0 . 0 0}$ & $\mathbf{1 0 0 . 0 0}$ & $\mathbf{1 0 0 . 0 0}$ & $\mathbf{1 0 0 . 0 0}$ & $\mathbf{1 0 0 . 0 0}$ & $\mathbf{1 0 0 . 0 0}$ & $\mathbf{1 0 0 . 0 0}$ \\
\hline
\end{tabular}

Source: General Administration of Customs, Cote d'Ivoire.

Table 2 presents the composition of imports by commodity types. It clearly shows that Cote d'Ivoire's import basket is dominated by consumer goods followed by intermediate goods and capital goods. Over the period 20022017, on average, 42.8 percent of Cote d'Ivoire's imports are consumer goods, 36.5 percent are intermediate goods, and 20.6 percent are capital goods. These figures clearly show the heavy reliance of the Ivorian economy on imported goods to meet the domestic demand of households and private sector.

\subsection{Econometric Methodology}


Most of the time series data faces the problem of nonstationarity due to the presence of unit root or time trend. In such situation regression results may be misleading (Granger and Newbold, 1974). Hence our empirical analysis involves three steps as described below. As a first step, we test for the order of integration of the series by using the PP unit root test of Phillips and Perron (1988) and the KPSS test of Kwiatkowski et al. (1992). In a second step, we test whether there is a long run relationship among the variables. For this purpose, we employ the Autoregressive Distributed Lag (ARDL) bounds testing approach to cointegration developed by Pesaran et al. (2001). This approach performs well in small samples without concerning whether the regressors are stationary at level (i.e. I(0)) or stationary in first difference (i.e. I(1)). Hence, it eliminates the uncertainty associated with pretesting the order of integration of the series in small samples.

To carry out the ARDL bounds test to cointegration, Eq.(2) is reformulated as a conditional error correction model as follows:

$$
\Delta \ln M_{t}=\theta_{0}+\theta_{1} \ln M_{t-1}+\theta_{2} Z_{t-1}+\sum_{i=1}^{p} \gamma_{1 i} \Delta \ln M_{t-i}+\sum_{i=0}^{q} \gamma_{2 i} \Delta Z_{t-i}+e_{t}
$$

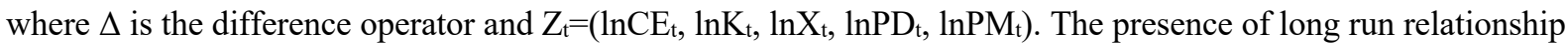
is tested by restricting coefficients of lagged level variables equal to zero. That is, the null hypothesis of no longrun relationship is $\mathrm{H}_{0}: \Theta_{1}=\Theta_{2}=0$. This hypothesis is tested through an $F$-test. Under the null hypothesis, however, the distribution of this F-statistic is non-standard, irrespective of whether the variables are integrated of order zero or one. Pesaran et al. (2001) have tabulated two sets of critical values that account for integrating properties of the variables. If the calculated F-statistic is higher (lower) than the upper (lower) critical value, then the null hypothesis of no cointegration can (cannot) be rejected.

The ARDL bounds testing procedure is sensitive to the selection of the lag structure $(p, q)$. In this study, maximum lag length on each variable was set to five and the optimal lag structure was selected using the AIC criterion. The model has been tested by the diagnostic tests that are serial correlation, normality test and heteroskedasticity test. The stability of the model has also been tested using the Brown et al. (1975) cumulative sum of recursive residuals (CUSUM) and the cumulative sum of squares of recursive residuals (CUSUMSQ). Once a long-run relationship is identified amongst the variables, the estimated long-run coefficients are obtained as the negative value of the coefficients for the lagged explanatory variables divided by the coefficient for the lagged dependent variable. The short-run coefficients are simply the estimated coefficients of the first differenced variables in the unrestricted error correction model.

\section{EMPIRICAL RESULTS}

We begin our empirical analysis by examining the stationarity of the variables. As indicated above, we apply the PP and KPSS tests. The results of unit root tests reported in Table 3 suggest that all the variables are non-stationary in their level but become stationary after taking the first difference. Thus, we can conclude that the variables under study are integrated of order one. Based on this result, the next step of our empirical investigation is to test for the existence of long-run relationships among the variables.

Table 3. Results of Unit Root Tests

\begin{tabular}{|c|c|c|c|c|}
\hline \multirow[b]{2}{*}{ Series } & \multicolumn{2}{|l|}{ Level } & \multicolumn{2}{|c|}{ First difference } \\
\hline & PP & KPSS & PP & KPSS \\
\hline $\ln \mathrm{M}$ & -2.768 & 0.074 & $-7.635^{*}$ & 0.059 \\
\hline $\ln C E$ & -0.665 & 0.112 & $-4.454^{*}$ & 0.082 \\
\hline $\operatorname{lnK}$ & -2.803 & 0.143 & $-9.191^{*}$ & 0.074 \\
\hline $\ln X$ & -2.112 & 0.141 & $-4.821^{*}$ & 0.070 \\
\hline $\ln P D$ & -1.875 & 0.086 & $-4.175^{*}$ & 0.084 \\
\hline $\ln P M$ & -3.375 & 0.061 & $-7.511^{*}$ & 0.100 \\
\hline
\end{tabular}

Note: $\mathrm{M}, \mathrm{CE}, \mathrm{K}, \mathrm{X}, \mathrm{PD}$, and PM denote real imports, real final consumption, real gross capital formation, real exports, domestic price and import price, respectively. The unit root tests have been performed under 
the model with constant and trend. 5\% critical values for PP and KPSS tests are -3.536 and 0.146 ,

respectively. * indicates the rejection of the null hypothesis at $5 \%$ level of significance.

To investigate the existence of long-run relationships between the variables, the bounds test is employed under the ARDL approach framework. The results are displayed in Table 4. The calculated F-statistics are compared with the critical values provided by Pesaran et al. (2001). The results show that a long-run relationship exists among the variables when import variable is used as dependent variable. In this case, the computed F-statistic value is greater than the upper bound critical value at $5 \%$ level of significance. The results also suggest a llongrunrelationship when exports variable is the dependent variable. Diagnostic tests such as serial correlation test, heteroskedasticity test, normal distribution test, and the stability test are used to ensure the reliability of the estimated models. The tests indicate that there are no serial correlation, no heteroskedasticity and normal distribution. The stability test also clearly demonstrates that the models are stable. We can, therefore, conclude that there is at least onlong-runun relationship between the variables.

Table 4. Results of the ARDL Cointegration Test

\begin{tabular}{|c|c|c|c|c|}
\hline \multirow[t]{2}{*}{ Model } & \multirow[t]{2}{*}{ F-stat. } & \multicolumn{3}{|c|}{ Diagnostic tests } \\
\hline & & Normality & Heteroskedasticity & Correlation \\
\hline $\mathrm{M}=\mathrm{f}(\mathrm{CE}, \mathrm{K}, \mathrm{X}, \mathrm{PD}, \mathrm{PM})$ & $7.692^{*}$ & $0.730[0.649]$ & $23.044[0.682]$ & $0.586[0.478]$ \\
\hline CE=f(M, K, X, PD, PM) & 3.207 & $0.636[0.727]$ & $32.079[0.271]$ & $1.047[0.353]$ \\
\hline $\mathrm{K}=\mathrm{f}(\mathrm{M}, \mathrm{CE}, \mathrm{X}, \mathrm{PD}, \mathrm{PM})$ & 3.125 & $1.315[0.518]$ & $29.246[0.452]$ & $0.046[0.830]$ \\
\hline $\mathrm{X}=\mathrm{f}(\mathrm{M}, \mathrm{CE}, \mathrm{K}, \mathrm{PD}, \mathrm{PM})$ & $7.271^{*}$ & $3.599[0.165]$ & $29.994[0.465]$ & $0.486[0.485]$ \\
\hline \multirow[t]{3}{*}{$\mathrm{PD}=\mathrm{f}(\mathrm{M}, \mathrm{CE}, \mathrm{K}, \mathrm{X}, \mathrm{PM})$} & 2.755 & $0.599[0.862]$ & $25.039[0.723]$ & $0.160[0.688]$ \\
\hline & \multicolumn{4}{|c|}{ Critical values $(\mathrm{T}=38)$} \\
\hline & \multicolumn{2}{|c|}{ Lower bounds I $(0)$} & Upper bounds I(1) & \\
\hline $1 \%$ & \multicolumn{2}{|c|}{2.82} & 4.21 & \\
\hline $5 \%$ & \multicolumn{2}{|l|}{2.14} & 3.34 & \\
\hline $10 \%$ & \multicolumn{2}{|l|}{1.81} & 2.93 & \\
\hline
\end{tabular}

Note: M, CE, K, X, PD and PM denote real imports, real final consumption expenditure, real capital formation, real exports, domestic price and import price, respectively. Lag length on each variable was selected using the AIC criterion with maximum lag set to 5. Critical values are those of the model with no intercept and trend. Figures in [.] are $p_{-}$values. . * indicates the rejection of the null hypothesis of no cointegration at $5 \%$ level of significance.

As cointegration exists among the variables, we further estimate the long-run elasticities of import demand with respect to each independent variable. We estimate the long-run relationship using the ARDL approach of Pesaran et al. (2001), the Fully Modified OLS (FMOLS) estimator proposed by Phillips and Hansen (1990), and the Dynamic OLS (DOLS) estimator suggested by Stock and Watson (1993). These three estimation techniques account for the possible endogeneity among the variables and have desirable properties in small samples. The results from these methods enable us to compare the long-run elasticities of import demand derived using alternative estimation methods. The results are summarized in Table 5. They show that the long-run coefficients on consumption expenditure, investment expenditure, domestic price and import price have their expected sign and have statistically significant impact on import demand in Cote d'Ivoire. The effects of expenditure components are different on aggregate import demand. The import demand is highly sensitive to domestic price followed by import price, consumption expenditure and investment expenditure in the long run. The consumption and investment expenditure components are positively related to import demand regardless of estimation methods. This indicates that an increase in consumption and investment expenditure components will lead to higher import demand as indicated by Keynesian absorption theory. This finding is consistent with the fact that a large proportion of Cote d'Ivoire's imports are consumer and capital goods. The positive and significant import demand elasticity with respect to domestic price implies than at increase in domestic prices leads to higher imports of goods and services. On the contrary, the coefficient on import price is expectedly negatively signed and significant. This implies that an increase in foreign prices will decrease imports and consequently reduce the import bill. For example, an increase in import price by $1 \%$ will reduce import demand by $1.84 \%$ and the import bill by $0.84 \%$.

Furthermore, the results show that the coefficient on expenditure on exports is not in accordance with economic theory which suggests a positive relationship between exports and imports. However, the coefficient on exports is 
not significant in two models. Overall, the elasticity estimates in Table 5 indicate that consumption expenditure, investment expenditure, domestic and import prices are the main determinants of Cote d'Ivoire's aggregate imports in the long run. In particular, consumption expenditure appears to dominate the influence of other components of final expenditure in the long run. Our results are not consistent with findings by N'Guessan and Yue (2010) who found that, in the long run, investment and export expenditures are the main determinants of Cote d'Ivoire's imports and that import demand is not sensitive to price changes. The difference in magnitude of the elasticities of import demand with respect to different expenditure components provides evidence in support to using different components of final expenditure separately in import demand function.

Table 5. Results of Estimated Long Run Import Demand Function

\begin{tabular}{|c|c|c|c|c|c|c|}
\hline \multirow{3}{*}{ Regressor } & \multicolumn{6}{|c|}{ Dependent variable: LnM } \\
\hline & \multicolumn{2}{|l|}{ ARDL } & \multicolumn{2}{|c|}{ FMOLS } & \multicolumn{2}{|l|}{ DOLS } \\
\hline & Coef. & t-stat. & Coef. & t-stat. & Coef. & t-stat. \\
\hline $\operatorname{lnCE}$ & $0.975^{*}$ & 2.385 & $0.519^{*}$ & 4.107 & $1.347^{*}$ & 2.632 \\
\hline $\ln K$ & $0.521^{*}$ & 3.442 & $0.296^{*}$ & 4.228 & $0.717^{*}$ & 9.037 \\
\hline $\ln X$ & -0.611 & -1.519 & 0.161 & 1.453 & $-1.284^{*}$ & -2.217 \\
\hline $\ln P D$ & $2.503^{*}$ & 2.640 & $0.752^{*}$ & 3.898 & $4.560^{*}$ & 2.999 \\
\hline $\ln P M$ & $-1.844^{*}$ & -2.546 & $-0.639^{*}$ & -4.016 & $-3.313^{*}$ & -3.001 \\
\hline \multicolumn{7}{|c|}{ Price homogeneity test } \\
\hline $\mathrm{H}_{0}: \beta_{4}+\beta_{5}=0$ & \multicolumn{2}{|c|}{$-2.850^{*}[0.029]$} & \multicolumn{2}{|c|}{$1.346[0.187]$} & \multicolumn{2}{|c|}{$2.964^{* *}[0.059]$} \\
\hline \multicolumn{7}{|c|}{$\begin{array}{l}\text { Note: The model estimated is: } \ln _{\mathrm{t}}=\beta_{0}+\beta_{1} \ln \mathrm{lE}_{\mathrm{t}}+\beta_{2} \ln \mathrm{K}_{\mathrm{t}}+\beta_{3} \ln \mathrm{X}_{\mathrm{t}}+\beta_{4} \operatorname{lnPD}_{\mathrm{t}}+\beta_{5} \ln \mathrm{PM} \mathrm{M}_{\mathrm{t}}+\mu_{\mathrm{t}} \text {, where } \mathrm{M}, \mathrm{CE}, \mathrm{K}, \mathrm{X}, \mathrm{PD} \\
\text { and PM denote real imports, real final consumption expenditure, real capital formation, real exports, domestic price } \\
\text { and import price, respectively. The restriction } \beta_{4}+\beta_{5}=0 \text { implies homogeneity price. Figures in [.] are } p \text { _values. The } \\
\text { asterisk * and } * * \text { denote statistical significance at the } 5 \% \text { and } 10 \% \text { levels, respectively. }\end{array}$} \\
\hline
\end{tabular}

To check whether the price homogeneity of import demand is appropriate, we test the linear restriction on price variables i.e. $\beta_{4}+\beta_{5}=0$. The results from the ARDL and DOLS models show that the hypothesis of price homogeneity should be rejected, implying that the relative price formulation of import demand is not appropriate in the case of Cote d'Ivoire. This result provides significant evidence for using domestic and import prices separately in import demand equation instead of relative price. The results clearly show that import demand is more sensitive to changes in domestic price than to import price.

Once cointegration among the variables is proved, we can estimate the short run dynamic model for import demand through an error correction model. Table 6 displays the short run elasticities of the import demand with respect to its determinants using the ARDL approach. According to the results, all expenditure components (consumption, investment and exports expenditures) have significant positive effects on import demand in the short run. The magnitude of impact of these expenditure components on the import demand is however different. Consumption expenditure has the highest elasticity of import demand and it is followed by exports and investment expenditures. The results also show that domestic price has a positive impact on imports while import price is negatively related to imports in the short run. The effects of domestic and import prices are consistent with a priori expectations. The coefficient on the lagged error correction term is statistically significant with the expected negative sign, confirming the existence of a long-run relationship among the variables.

Table 6. Short Run Import Demand Function using the ARDL Model

\begin{tabular}{llll}
\hline Regressor & \multicolumn{3}{l}{ Dependent variable: $\Delta \operatorname{lnM}$} \\
\cline { 2 - 4 } & Coef. & t-stat. & Prob. \\
\hline$\Delta \ln C E$ & $0.654^{*}$ & 2.357 & 0.026 \\
$\Delta \ln K$ & $0.134^{*}$ & 3.487 & 0.001 \\
$\Delta \ln \mathrm{N}$ & $0.181^{* *}$ & 1.714 & 0.098 \\
$\Delta \ln \mathrm{PD}$ & $1.100^{*}$ & 5.334 & 0.000 \\
$\Delta \ln \mathrm{PM}$ & $-1.007^{*}$ & -11.605 & 0.000 \\
$\mathrm{ECT}(-1)$ & $-0.620^{*}$ & -9.198 & 0.000 \\
\hline
\end{tabular}


Note: M, CE, K, X, PD and PM denote real imports, real final consumption, real capital formation, real exports, domestic price and import price, respectively. The asterisks * denotes statistical significance at the $5 \%$ level.

\section{CONCLUSION}

The study has examined the aggregate import demand function for Cote d'Ivoire. The Autoregressive Distributed Lag (ARDL) modelling technique was used to examine the relationship between aggregate imports and disaggregated components of final demand for the period 1980 to 2017. We disaggregated components of final demand into three components that are final consumption expenditure, investment expenditure and expenditure on exports. The bounds test results show that there islong-runrun relationship between aggregate import demand and its determinants. We then estimate the long run elasticities of import demand with respect to its determinants. The robustness of the results was further checked using the Fully Modified Ordinary Least Squares (FMOLS) and the Dynamic Ordinary Least Squares (DOLS) techniques.

The results of the study reveal that significant determinants of Cote d'Ivoire's aggregate imports in the long run are final consumption expenditure, investment expenditure, domestic and import prices. Domestic and import prices have the largest long run effects on the demand for imports. Moreover, there are significant differences between the long run elasticities of imports with respect to different components of aggregate expenditure. Final consumption and investment expenditures were found to be the major determinants of import demand in the long run. This is not surprising given that consumer and capital goods have the largest share to imports in Cote d'Ivoire. The import elasticity of demand with respect to exports is negative and insignificant. In the short run, all expenditure components are positively related to import growth, with consumption expenditure having the highest effect on import growth. Results of the short run import demand also show that consumption expenditure, investment expenditure, exports expenditure, domestic and import prices are all significant determinants of import demand. All variables except import price show a positive effect on imports in the short run.

Our results show the importance of using disaggregated expenditure components given that they have different impacts on import demand. In addition, the results of this study reject the price homogeneity assumption and show that import demand is more sensitive to domestic price than to import price. This finding provides strong evidence of using domestic and import prices separately in estimating import demand function instead of relative price. Therefore, the relative price formulation is inappropriate in estimating import demand function for Cote d'Ivoire.

These empirical results have significant policy implications on the economic policies designed to improve trade performance and the balance of payment. Firstly, given the large influence of final consumption expenditure on import demand, fiscal policies designed to influence the pattern of consumption expenditure in Cote d'Ivoire are essential to reduce imports and hence improve external balance. Government should thus create the enabling environment to increase domestic productive capacity in order to reduce imports especially on consumer goods such as rice, which can be produced locally. By increasing domestic productive capacity, the export base will be broadened, which will increase exports and hence improve the trade balance. Secondly, the estimated domestic price elasticity suggests that an increase in domestic inflation will result in an increase in imports. This suggests that efforts should be done to control for inflation by keeping it at a low level.

\section{References}

Abbott, A. J. and Seddighi, H. R. (1996). Aggregate Imports and Expenditure Components in the U.K.: An Empirical Analysis. Applied Economics, 28(9), 1119-1125.

Arize, A.C., J. Malindretos, and E.C. Grivoyanis (2004). Foreign Exchange Reserves and Import Demand in a Developing Country: The Case of Pakistan. International Economic Journal, 18(2), 259-274.

Babatunde, M. A., and Egwaikhide, F. O. (2010). Explaining Nigeria's Import Demand Behaviour: A Bound Testing Approach. International Journal of Development Issues, 9(2), 167-187. 
Bahmani-Oskooee, M. and Niroomand, F. (1998). Long-Run Price Elasticities and the Marshall-Lerner Condition Revisited. Economics Letters, 61(1), 101-109.

Bathalomew, D. (2010). An Econometric Estimation of the Aggregate Import Demand Function for Sierra Leone. Journal of Monetary and Economic Integration, 10(1), 5-24.

Chang, T., Y. Ho, and Huang, C. (2005). A Re-examination of South Korea's Aggregate Import Demand Function: A Bounds Test Analysis. Journal of Economic Development, 30(1), 119-128.

Chani, M. I., Pervaiz, Z. and Chaudhary, A. R. (2011). Determination of Import Demand in Pakistan: The Role of Expenditure Components. Theoretical and Applied Economics, 8(8), 93-110.

Chantha H., Keo, K. and C. Suttiprapa (2018). An Empirical Analysis of Cambodia's Import Demand Function. Journal of Management, Economics, and Industrial Organization, 2(1), 1-12.

Chimobi, O. P. and Ogbonna, B. C. (2008). Estimating Aggregate Import Demand Function in Nigeria: A Cointegration Approach. Journal of Research in National Development, 6(1), 170-182.

Deaton, A. and Muellbauer, J. (1980). Economics and Consumer Behaviour. Cambridge: Cambridge University Press.

Doroodian, K., R. K. Koshal, and S. Al-Muhanna (1994). An Examination of the Traditional Aggregate Import Demand Function for Saudi Arabia. Applied Economics, 26, 909-915.

Dutta, D. and N. Ahmed (1999). An Aggregate Import Demand Function for Bangladesh: A Cointegration Analysis Approach. Applied Economics, 31, 465-472.

Dutta, D. and N. Ahmed (2004). An Aggregate Import Demand Function for India: A Cointegration Approach. Applied Economics, 11(10), 607-613.

Faini, R., L. Pritchett, and F. Clavijo (1992). Import Demand in Developing Countries, in Dagenais, M.G., and P.A. Muet, eds., International Trade Modelling, New York: Chapman \& Hall, 279-297.

Fosu, O. E. and Magnus, F. J. (2008). Aggregate Import Demand and Expenditure Components in Ghana. Journal of Social Sciences, 4(1), 1-6.

Giovannetti, G. (1989). Aggregate Imports and Expenditure Components in Italy: An Econometric Analysis. Applied Economics, 21(7), 957-971.

Goldstein, M. and M.S. Khan (1985). Income and Price Effects in Foreign Trade, in Jones, R. W., \& P. B. Kenen (ed.), Handbook of International Economics, Vol. 2: 1041-1105. New York: Elsevier.

Granger, C. and Newbold, P. (1974). Spurious Regressions in Econometrics. Journal of Econometrics, 2, 111120.

Ibrahim A. and Ahmed, E. M. (2017). The Determinants of Aggregate Demand Function of Sudan. Business Economics Journal, 8:3, DOI: 10.4172/2151-6219.1000309.

Kwiatkowski, D., Phillips, P. C. B., Schmidt, P. and Shin, Y. (1992). Testing the null Hypothesis of Stationarity against the Alternative of a Unit Root. Journal of Econometrics, 54, 159-178.

Marbuah, G. (2013). Modelling Import Demand Behaviour in Ghana: A Re-examination. Economics Bulletin, 33(1), 482-493.

Min, B. S., Mohammed, H.A. and Tang, T.C. (2002). An Analysis of South Korea's Import Demand. Journal of Asia Pacific Affairs, 4(1), 1-17.

Modeste, N. C. (2011). An Empirical Analysis of the Demand for Imports in Three CARICOM Member Countries: An Application of the Bounds Test for Cointegration. Review of Black Political Economy, 38, 53-62.

Mohammad, H. A. and Tang, T.C. (2000). Aggregate Imports and Expenditure Components in Malaysia: A Cointegration and Error Correction Analysis. ASEAN Economic Bulletin, 17(3), 257-269.

Mugableh, M. I. (2017). Estimating Elasticity Function of Jordanian Aggregate Import Demand. Applied Economics and Finance, 4(2), 33-37.

Muhammad, S. D. and Zafar, S. (2016). Determinants of Import Demand Functions of Pakistan: An ARDL Bound Testing Approach. International Journal of Business, Economics and Management, 3(9), $113-121$.

Murray, T. and Ginman, P. (1976). An Empirical Examination of the Traditional Aggregate Import Model. The Review of Economics and Statistics, 58, 75-80.

Mwega, F. M. (1993). Import Demand Elasticities and Stability during Trade Liberalization: A Case Study of Kenya. Journal of African Economies, 2, 381-416.

Narayan, S. and Narayan, P.K. (2005). An Empirical Analysis of Fiji's Import Demand Function. Journal of Economic Studies, 32(2), 158-168.

N'Guessan, C. Z. S. and Yue, Y. (2010). An Econometric Estimation of Import Demand Function for Cote d'Ivoire. International Journal of Business and Management, 5(2), 77-84.

Nwogwugwu, U. C., Maduka, A. C. and Madichie, C. V. (2015). Price and Income Elasticities of Import Demand in Nigeria: Evidence from the Bound Testing Procedure. International Journal of Development and Economic Sustainability, 3(4), 91-103.

Pesaran H., Shin, Y. and Smith, R. J. (2001). Bounds Testing Approaches to the Analysis of Level Relationships. Journal of Applied Econometrics, 16(3), 289-326. 
Phillips, P. C. B. and Perron, P. (1988). Testing for a Unit Root in a Time Series Regression. Biometrika, 75(2), $335-346$.

Phillips, P.C.B. and Hansen, B. E. (1990). Statistical Inference in Instrumental Variables Regression with I(1) Process. The Review of Economic Studies, 57, 99-125.

Raijal, A., R. K. Koshal and C. Jung (2000). Determinants of Nepalese Imports. Journal of Asian Economics, 11, $347-354$.

Sinha, S. (1997). Determinants of Import Demand in Thailand. International Economic Journal, 11(4), 73-83.

Stock, J. and Watson, M. W. (1993). A Simple Estimator of Cointegrating Vectors in Higher Order Integrated Systems. Econometrica, 61(4), 783-820.

Tang, T. C. and Nair, M. (2002). A Cointegration Analysis of Malaysian Import Demand Function: Reassessment from the Bounds Test. Applied Economics Letters, 9(5), 293-296.

Tang, T. C. (2003). An Empirical Analysis of China's Aggregate Import Demand Function. China Economic Review, 14(2), 142-163.

Tsionas, E. G. and Christopoulos, D. K. (2004). International Evidence on Import Demand. Empirica, 31(1), $43-$ 53.

Urbain, J. P. (1993). Exogeneity in Error Correction Models. Springer-Verlag, Berlin Heidelberg, New York.

Xu, X. (2002). The Dynamic-Optimizing Approach to Import Demand: A Structural Model. Economics Letters, $74,265-270$.

Yin, F. and S. Hamori (2011). Estimating the Import Demand Function in the Autoregressive Distributed Lag Framework: The Case of China. Economics Bulletin, 31(2), 1576-1591.

Ziramba, E. (2012). Revisiting the South African Aggregate Import Demand: A View from Expenditure Components. Journal for Studies in Economics and Econometrics, 36(2), 67-83. 